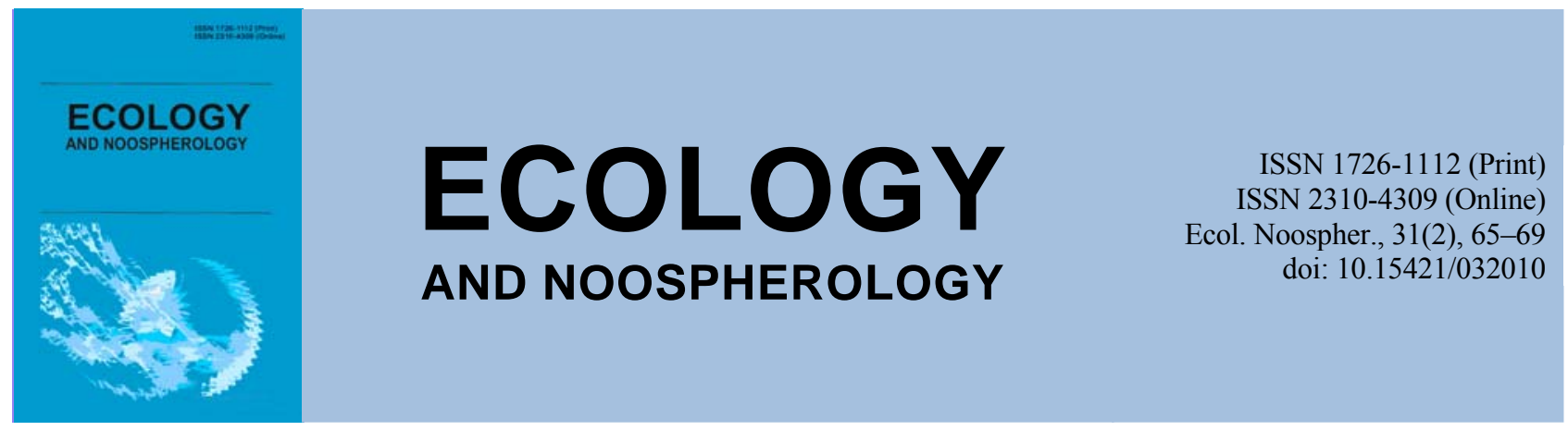

\title{
Effect of ravined forest biogeocenoses on soil humus status in a steppe environment
}

\author{
K. M. Bozhko, A. O. Dubina, V. O. Matsyuk \\ Oles Honchar Dnipro National University, Dnipro, Ukraine
}

Article info

Received 14.06.2020

Received in revised form

20.06.2020

Accepted 24.06.2020

Oles Honchar Dnipro

National University

Gagarin Ave., 72, Dnipro,

49010, Ukraine.

Tel.: +38-050-274-73-56

E-mail:bozhko.k.n@gmail.com
Bozhko, K. M., Dubina, A. O., Matsyuk, V. O. (2020). Effect of ravined forest biogeocenoses on soil humus status in a steppe environment. Ecology and Noospherology, 31(2), 65-69. doi:10.15421/032010

A detailed study of the relationships between all components of each biogeocenosis is needed for its in-depth investigation. According to the concept of biogeocenoses developed by V. M. Sukachev, soil is one of the five components of biogeocenosis being its resulting unit. Soil is a bioinert component body of biogeocenosis. Playing the role of a subsystem, it is characterized by self-regulation, stability, direct and feedback mechanisms, self-restoring fertility, a specific biological cycle of substances and energy flow against the background of a specific natural geographical area. When the soil testing, its chemical, physical, water, micromorphological properties should be determined, and, above all, a total humus content and quality. Humus affects all important soil properties. In fertility, its essential role consists in a nutrient source as a factor that has a physiological effect on plants. A role of humus in improving the physical, thermal and water properties of soils is well-known. The total content and group composition of humus are also determined during the diagnosis and classification of soils. For a more detailed description of humus, Grishina and Orlov proposed a system of indicators of soils humus condition. This is a level of humus content and reserves, its profile distribution, type of humus, degree of humification, etc. In this work, we made an attempt to diagnose the soils of ravined biogeocenoses and steppe virgin lands in Dnipropetrovsk region on the basis of a number of the above parameters. To compare, the common steppe virgin chernozem and forest chernozems of the northern and southern variants of the ravines were used. The study was carried out in the fresh linden-ash oakery (the Kapitanovsky Bayrak) and in the fresh maple oakery (the Viyskovoy Bayrak) occured in the middle part of the slopes of the northern exposition. The paper presents data on the study of the ravined forest biogeocenoses influence on the total content and qualitative composition of soil humus in the northern and southern variants of Dnipropetrovsk region in comparison with the steppe virgin soil. It was established that the total humus content and reserves in the layer of $0-20 \mathrm{~cm}$ increased and varied from moderate to high under the influence of ravined forest vegetation; the type of humus turns from humate to fulvate-humate, which has a positive effect on plant growth and development, as it makes nutrients more mobile and available to plants. Under the influence of forest vegetation in the ravines, the soil humus condition improved, namely, the total humus content and reserves in the $20 \mathrm{~cm}$ layer varied from moderate to high, and the type of humus turned from humate to fulvatehumate. Our data confirmed O. L. Belgard and A. P. Travleev provisions that forests in the steppe zone effect positively on soil properties, in particular their humus condition, in contrast to the forest zone.

Keywords: biogeocenosis; ravine; soil; humus; humus condition; northern and southern variant of ravines

\section{Вплив байрачних лісових біогеоценозів на гумусовий стан грунтів в умовах степу}

\author{
К. М. Божко, А. О. Дубина, В. О. Мацюк
}

Дніпровський національний університет імені Олеся Гончара, Дніпро, Україна 
У цій роботі ми зробили спробу діагностувати грунти байрачних біогеоценозів та степової цілини Дніпропетровщини на основі рівня вмісту і запасів гумусу, його профільного розподілу, типу гумусу, ступеня гуміфікації та ін. (показники гумусового стану за Гришиною та Орловим). Для порівняння були взяті чорнозем звичайний степової цілини і чорноземи лісові північного і південного варіантів байраків. Дослідження проводились у свіжій липово-ясеневій діброві байраку Капітанівського та в свіжій пакленовій діброві байраку Військового, які зустрічаються в середній частині схилів північної експозиції. У роботі наведено дані з вивчення впливу байрачних лісових біогеоценозів північного і південного варіантів Дніпропетровщини на загальний уміст та якісний склад гумусу грунту в порівнянні з грунтом степової цілини. Установлено, що під впливом лісової рослинності байраків загальний уміст гумусу і запаси його в шарі 0-20 см збільшуються, змінюються від середніх до високих; тип гумусу переходить від гуматного до фульватно-гуматного, що має позитивний вплив на ріст і розвиток рослин, оскільки робить поживні речовини більш рухомими і доступними для рослин. Під впливом лісової рослинності в байраках гумусовий стан грунтів покращується, а саме загальний уміст та запаси гумусу в 20-сантиметровому шарі змінюються від середніх до високих, а тип гумусу - від гуматного до фульватно-гуматного. Наші дані підтвердили положення професорів О. Л. Бельгарда та А. П. Травлєєва, що ліси в степовій зоні, на відміну від лісової зони, позитивно впливають на властивості грунту, зокрема на їх гумусовий стан.

Ключові слова: біогеоценоз; байрак; грунт; гумус; гумусовий стан; північний і південний варіанти байраків; чорнозем лісовий; чорнозем звичайний

\section{Вступ}

Для збереження біорізноманіття екосистем виникла тенденція до створення стійкої екологічної сітки, в якій міцно та гармонійно можуть співіснувати природні та штучні біогеоценози (Nikiforov, 2008). У такій екологічній мережі байрачні ліси південно-східної України виступають у ролі ядра, займаючи одне з вагомих місць.

Байрачні біогеоценози мають величезну наукову цінність для дослідження особливостей формування природних лісів, де знайшли собі притулок рідкісні i зникаючі види флори та фауни степової зони України та суміжних територій степів. Ліси $\epsilon$ також еталонами протиерозійних насаджень в умовах приводороздільнобалкових ландшафтів південного сходу України (Belova, Travleyev, 1999).

Відомо, що лісові насадження степу мають позитивні багатофункціональні властивості. Вони припиняють або зменшують вплив сухих східних та північно-східних вітрів, перетворюють поверхневий стік води на глибинний, покращують родючість грунтів, створюють сприятливі умови для отримання високих i стабільних урожаїв, підвищують продуктивність луків та пасовищ тощо (Belgard, 1950; Belova, Travleyev, 1999).

Для глибокого дослідження кожного біогеоценозу необхідно детально вивчати взаємозв'язки всіх його компонентів. За вченням В. М. Сукачова про біогеоценоз (Sukachov, 1964), грунт є одним із п'яти компонентів біогеоценозу, його результуючим блоком. Грунт - це біокосне компонентне тіло біогеоценозу. Відіграючи роль підсистеми, він характеризується саморегуляцією, стійкістю, прямими та зворотними зв'язками, родючістю, що самовідновлюється, специфічним біологічним кругообігом речовин та потоку енергії на фоні конкретної природно-географічної зони (Zonn, 1964).

Під час дослідження грунтів визначають його хімічні, фізичні, водні, мікроморфологічні властивості і в першу чергу загальний уміст та якісний склад гумусу (Grishuna \& Orlov, 1978).

Гумус впливає на всі важливі властивості грунту. В родючості суттєва роль його полягає як джерела елементів живлення, як фактора, який чинить фізіологічну дію на рослини. Відома роль гумусу в покращенні фізичних, теплових, водних властивостей грунтів. Загальний уміст $\mathrm{i}$ груповий склад гумусу визначаються також при проведенні діагностики та класифікації грунтів (Grishina \& Orlov, 1978).

Для більш детальної характеристики гумусу Гришина та Орлов запропонували систему показників гумусового стану грунтів. Це - рівень умісту і запаси гумусу, його профільний розподіл, тип гумусу, ступінь гуміфікації та ін. (Grishina \& Orlov, 1978).

У цій роботі ми зробили спробу діагностувати грунти байрачних біогеоценозів та степової цілини
Дніпропетровщини на основі ряду вищевказаних параметрів.

Для порівняння були взяті чорнозем звичайний степової цілини і чорноземи лісові північного і південного варіантів байраків.

\section{Об’єкти та методи досліджень}

Об'єкт дослідження - грунти степових та північного і південного варіантів байрачних лісових біогеоценозів Дніпропетровщини.

Методологічний підхід досліджень базується на вченні В. М. Сукачова про біогеоценоз, С. В. Зонна про грунт як компонент лісового біогеоценозу (Zonn, 1964), типології природних лісів степової зони О. Л. Бельгарда (Belgard, 1971). Польові дослідження, геоботанічний опис, визначення біоекологічної характеристики флори виконані на основі загальноприйнятих біогеоценотичних методів $\mathrm{i}$ досліджень. Типологічна формула байрачних біогеоценозів визначалась за О. Л. Бельгардом (Belgard, 1950).

Загальний уміст гумусу та груповий склад його визначався за методикою Орлова Д. С. і Гришиної Л. А. (Orlov \& Grishina, 1981), гумусовий стан - за Гришиною Л. А. і Орловим Д. С. (Grishina \& Orlov, 1978), Запаси гумусу розраховували за формулою: щільність $\left(г / \mathrm{cm}^{3}\right) \times$ потужність грунтового горизонту (см) $\times$ вміст гумусу (\%). Запаси гумусу обчислювали для окремих горизонтів грунту, а потім підсумовували запаси для 20-сантиметрової товщі.

За приклад північного варіанта байрачних лісів Дніпропетровщини згідно з класифікацією О. Л. Бельгарда (Bel'gard, 1950) нами був вибраний байрак Капітанівський, який знаходиться у Новомосковському районі Дніпропетровської області поблизу села Надіївка.

Пробна площа ПП-БК-2 розташована в середній третині схилу в $10^{\circ}$ північної експозиції у 55 м від тальвегу балки в свіжій липово-ясеневій діброві із зірочником. Тип лісорослинних умов - суглинок свіжий. Тип світлової структури - тіньовий, III віковий ступінь. Тип деревостану 4Дз2Кг2Лс2Яз 80-100-річного віку, зімкнутість крони $0,8-0,9$. Умови зволоження - атмосферно-транзитні припливно-відпливні.

Чагарниковий підлісок 3 бруслини європейської (Euonymus europaea L.) та бородавчастої (Euоnymus verrucosa Scop.).

Трав'яний покрив фрагментарний, домінує зірочник лісовий (Stellaria nemorum L.), купина багатоквіткова (Polygonatum multiflorum (L) All.), копитняк європейський (Asarum europaeum L.).

Типологічна формула:

$$
\mathrm{Dac} \frac{\mathrm{Cr}_{\mathrm{z}}}{\mathrm{TH} \text { ч-II }} 4 \text { Дз2Кг } 2 \text { Лс2Яз }
$$

Лісова підстилка суцільна, двошарова, потужність 2,5$3,5 \mathrm{~cm}$. 
Грунт - чорнозем лісовий, середньолесивований, багатогумусовий, слабовилугований суглинистий на лесовидних відкладеннях.

Характеристика трунтового розрізу:

$\mathrm{H}_{0}{ }^{1}$ 0-1,5 см. Лісова підстилка 3 напіврозкладеного, напівсклеєного листя деревних порід.

$\mathrm{H}_{0}^{2} 1,5-2,5$ см. Трухоподібна маса бурого кольору, відокремлюється від грунту.

$\mathrm{Hel}_{1}$ 0-10 см. Темно-сірий, майже чорний, вологий, гумусово-елювіальний горизонт, пухкий, багатокорененасичений, великопористий. Горизонт майже повністю складається з екскрементів дощових черв'яків та інших представників грунтової мезофауни. Зустрічається велика кількість рослинних залишків на різних стадіях розкладення.

$\mathrm{Hel}_{2}$ 10-65 см. Темно-сірий, вологий, зернистодрібнозернистий, рихлий, суглинистий. Закипання грунту від $\mathrm{HCl}$ на глибині $43 \mathrm{~cm}$.

Hpil 65-77 см Темно-сірий, 3 буруватим відтінком, колір поступово світлішає, помітно щільніший, зернистодрібнозернистий, суглинистий.

Нp 77-90 см Темно-бурий з палевим відтінком, значно світлішає та щільнішає залежно від глибини. Колір від світло-бурого до бурого.

$\mathrm{Ph}$ 90-115 см Значно світліший, дуже щільний, поступово переходить у лесоподібний суглинок.

Нікольські байраки колишньої порожистої частини Дніпра, куди відноситься байрак Військовий, розміщені в більш засушливій частині області, тому із деревостану в них випадає ясен, що призводить до зменшення швидкості розкладання підстилки, накопичення більших запасів підстилки і більшої кількості гумусу в грунті в порівнянні 3 байраками північного варіанта (Dubina, 1972).

Пробна площа ПП-БВ-2 розташована в середній третині схилу в $7^{\circ}$ північної експозиції на відстані 15 м від тальвегу балки в свіжій пакленовій діброві з яглицею. Тип лісорослинних умов - суглинок свіжий. Тип світлової структури - тіньовий, III віковий ступінь. Тип деревостану 9Дз1Кп 100-річного віку, зімкнутість крони - 0,9. Умови зволоження - атмосферно-транзитні припливно-відпливні.

У першому деревному під'ярусі представлений дуб звичайний (Quercus robur L.): a) дуб звичайний порослевий двостовбурний 3 діаметром стовбурів по 45 см; б) дуб звичайний порослевий двостовбурний 3 діаметром стовбурів 30 см, 15 см, висотою 14 м, віком 40 років; в) дуб звичайний порослевий двостовбурний 3 діаметром стовбура 55 см, 60 см, висотою 18-20 м; клен польовий насінний (Acer campestre L.) 3 діаметром стовбура 9 см. Підріст $з$ клена польового (Acer campestre L.), клена татарського (Acer tataricum L.).

Чагарниковий підлісок 3 бруслини європейської (Euonymus europaea L.), самосів 3 бруслини бородавчастої (Euonymus verrucosa Scop) висотою 10 см, покриттям $1 \%$.

Загальне покриття травостою - $90 \%$.

Лісова підстилка суцільна, двошарова, з листя дуба звичайного потужністю $3 \mathrm{~cm}$.

Типологічна формула:

\section{Dn $\frac{\mathrm{C \Gamma}_{2}}{\text { Tir ч }- \text { III }} 9$ म $11 \mathrm{~K}$}

Грунт - чорнозем лісовий, карбонатний, лесивований, багатогумусовий, потужний, середньосуглинистий на делювіальних відкладеннях.

Характеристика трунтового розрізу

$\mathrm{H}_{0}{ }^{1} \quad 0-1,5 \quad$ см. Суцільна лісова підстилка 3 напіврозкладеного, напівсклеєного листя дуба звичайного, пухка, темно-бура.

$\mathrm{H}_{0}^{2} 1,5-3$ см. Трухоподібна маса темно-бурого кольору, розсипчаста, погано відокремлюється від грунту.

$\mathrm{Hel}_{1}$ 0-10 см. Темно-сірий, майже чорний, свіжий, гумусовий горизонт горіхувато-зернистої структури.
$\mathrm{Hel}_{2}$ 10-25 см. Темно-сірий, майже чорний, свіжий, горіхувато-зернистий-дрібнозернистий, карбонатний пухкий суглинок. Закипання на глибині 45 см. Перехід поступовий.

Hil 25-70 см. Темно-сірий, майже чорний, свіжий, горіхувато-дрібнозернистий, пухкий, карбонатний, суглинистий, щільніший.

Hpil 70-100 см. Темно-сірий, гумусовий, свіжий, колір поступово світлішає, дрібнозернистий, суглинистий, карбонатний, щільнішої структури.

Пробна площа ПП-СВ-1 (степова цілина) закладена на ділянці степу Солонянського району Дніпропетровської області. Схил $1,5^{\circ}$ північно-східної експозиції. Умови зволоження - атмосферно-транзитні припливно-відпливні. Багато пориїв сліпака. Тип лісорослинних умов - суглинок сухий $\left(\mathrm{C} \Gamma_{1}\right)$.

Трав'яний покрив характеризується щільною зімкненістю. Це переважно костриця валіська (Festuca valesiaca Gaud), келерія сиза (Koeleria glauca), льон шорсткий (Linum hirsutum L.), льон Черняєва (Linum czerniaevii Klokov), чебрець Маршаллів (Thymus Marschallianus Willd), ковила Лессінга (Stipa lessingiana Trin. et Rupr.), астрагал український (Astragalus ucrainicus M. Pop.et Klokov), жовтушник розлогий (Erysimum diffusum Ehth.), молочай степовий (Euphorbia stepposa Zoz. Ex Prokh.), льонолисник польовий (Thesium arvense Horvatovszky), нечуйвітер волохатенький (Hieracium pilostlla L.), молочай Сегієрів (Euphorbia seguierana Neck.), подорожник степовий (PIantago stepposa Kuprijan.), дивина фіолетова (Verbascum phoeniceum L.), шавлія поникла (Salvia nutans L.), чистець прямий (Stachys recta L.).

Грунти алювіальної групи, генетичний тип - чорнозем звичайний сильнокарбонатний малогумусовий середньосуглинистий.

Характеристика трунтового розрізу:

$\mathrm{H}_{0}$ 0-3 см. Степовий калдан із рослинних залишків різного ступеня розкладеності від свіжих до добре розкладених, потужність 3 см.

$\mathrm{H}_{1} \quad 0-10$ см. Верхній горизонт грунтового розрізу представлений темно-сірим сухуватим суглинком. Горизонт досить дерновий, дуже насичений корінням чисельних представників флори. Закипання грунту від $\mathrm{HCl}$ на глибині $9 \mathrm{~cm}$.

$\mathrm{H}_{2}$ 10-34 см. 3 глибиною стає менш насиченим корінням і більш щільнішим та трохи світлішим.

$\mathrm{H}_{\mathrm{Pk}}$ 34-56 см. Темно-сірий, буруватий, дрібнозернистий, свіжий карбонатний горизонт.

$\mathrm{P}_{\mathrm{h}}$ 56-100 см. Свіжий, щільний, світліший горизонт. 3'являється багато новоутворень $\left(\mathrm{CaCO}_{3}\right)$. Поступово переходить у лесоподібну материнську породу.

\section{Результати та їх обговорення}

Дослідження чорноземів лісових в байрачному лісі північного варіанта показали, що у верхньому горизонті грунтового профілю загальний уміст гумусу високий $-8,83 \%$ (табл. 1). Запаси гумусу розраховані для 20-см шару також високі - 165,0 т/га. Гумусовий горизонт потужний.

Профільний розподіл гумусу поступово спадний. Ступінь гуміфікації (доля гумінових кислот в складі органічної речовини грунту) змінюється від високого до дуже високого (34,0-61,0 \%).

Тип гумусу (співвідношення гумінових і фульвокислот) гуматний $\left(\mathrm{C}_{\text {гк }} / \mathrm{C}_{\phi к}=5,0-1,9\right)$. Уміст негідролізованого залишку $€$ середнім та низьким - $(24,3-53,1)$.

Як видно $з$ таблиці, у верхньому горизонті грунтового розрізу чорноземів лісових в байрачному лісі південного варіанта (ПП-БВ-2) вміст гумусу високий $(9,3 \%)$, запаси гумусу в горизонті 0-20 см (180 т/га) за показниками гумусового стану високі (табл. 2). Профільний розподіл гумусу поступово спадний, гумусовий горизонт потужний. 
Таблиця 1

Показники гумусового стану чорнозему лісового ПП-БК-2

\begin{tabular}{ccccc}
\hline Горизонт, см & Загальний уміст гумусу, \% & $\mathrm{C}_{\text {гк }} / \mathrm{C}_{\text {заг }} \times 100 \%$ & $\mathrm{C}_{\text {гк }} / \mathrm{C}_{\text {фк }}$ & $\begin{array}{c}\text { С залишку } \\
\text { до } \mathrm{C}_{\text {заг }} \times 100 \%\end{array}$ \\
\hline $\mathrm{Hel}_{1}$ 0-10 & 8,83 & 58,9 & 5,0 & 31,0 \\
$\mathrm{Hel}_{2}$ 10-65 & 6,13 & 34,0 & 2,4 & 53,1 \\
$\mathrm{Hpil} \mathrm{65-77}$ & 3,40 & 61,0 & 2,4 & 25,9 \\
$\mathrm{Hp} \mathrm{77-90}$ & 1,60 & 44,1 & 1,9 & 24,3 \\
\hline
\end{tabular}

Таблиця 2

Показники гумусового стану чорнозему лісового ПП-БВ-2

\begin{tabular}{ccccc}
\hline Горизонт, см & Загальний уміст гумусу, \% & $\mathrm{C}_{\text {гк }} / \mathrm{C}_{\text {заг }} \times 100 \%$ & $\mathrm{C}_{\text {гк }} / \mathrm{C}_{\text {фк }}$ & $\begin{array}{c}\mathrm{C} \text { залишку } \\
\text { до } \mathrm{C}_{\text {заг }} \times 100 \%\end{array}$ \\
\hline $\mathrm{Hel}_{1} 0-10$ & 9,30 & 36,7 & 2,3 & 53,1 \\
$\mathrm{Hel}_{2} 10-25$ & 8,76 & 31,1 & 2,2 & 51,3 \\
$\mathrm{Hil} \mathrm{25-70}$ & 6,40 & 29,2 & 2,0 & 54,6 \\
Hpil 70-100 & 3,76 & 29,1 & 1,9 & 55,8 \\
\hline
\end{tabular}

Тип гумусу змінюється від гуматного до фульватно-гуматного $\left(\mathrm{C}_{\mathrm{r \kappa}} / \mathrm{C}_{\phi к}=2,3-1,9\right)$, ступінь гуміфікації 3 глибиною грунтового розрізу змінюється від високого до середнього $(36,7-29,1)$. Вміст негідролізованого залишку середній $(51,3-55,8$ \%).
Загальний уміст гумусу $(5,21 \%)$ чорнозему звичайного і запаси гумусу в шарі 0-20 см (150 т/га) $є$ середніми, гумусовий шар потужний, профільний розподіл гумусу в метровій товщі $є$ поступово спадним (табл. 3).

Таблиця 3

Показники гумусового стану чорнозему звичайного ПП-СВ-1

\begin{tabular}{|c|c|c|c|c|}
\hline Горизонт, см & Загальний уміст гумусу, \% & $\mathrm{C}_{\text {гк }} / \mathrm{C}_{\text {заг }} \times 100 \%$ & $\mathrm{C}_{\text {гк }} / \mathrm{C}_{\phi \kappa}$ & $\begin{array}{c}\text { С залишку } \\
\text { до } \mathrm{C}_{3 а г} \times 100 \%\end{array}$ \\
\hline $\mathrm{H}_{1} 0-10$ & 5,21 & 68,0 & 3,6 & 14,2 \\
\hline $\mathrm{H}_{2} 10-34$ & 3,60 & 69,2 & 3,1 & 7,2 \\
\hline $\mathrm{H}_{\mathrm{Pk}} 34-56$ & 2,80 & 71,4 & 4,2 & 11,8 \\
\hline$P_{h} 56-100$ & 1,38 & 63,1 & 4,4 & 23,0 \\
\hline
\end{tabular}

Ступінь гуміфікації органічної частини грунту дуже високий: від 71,4 \% до 63,1 \% в нижньому горизонті.

Тип гумусу у всіх грунтових горизонтах гуматний $\left(\mathrm{C}_{\mathrm{r}} / \mathrm{C}_{\phi}=\right.$ $3,1-4,4)$.

Вміст негідролізованого залишку по всьому грунтовому профілі низький (7,2-23,0 \%).

На рис. 1 добре видно, що найбільший уміст гумусу у грунтах досліджуваних біогеоценозів - під байрачною лісовою рослинністю, а найменший - у степовій цілині.

Згідно 3 даними Д. С. Орлова (Grishina \& Orlov, 1978), чорноземи звичайні на ділянці степу Солонянського району Дніпропетровської області (як еталонні чорноземи) належать до малогумусових грунтів.

Лісові чорноземи під обома варіантами байрачних лісів належать до багатогумусових грунтів.

\section{Висновки}

На основі вивчення гумусового стану грунтів степової цілини, байраків Капітанівського та Військового на Дніпропетровщині можна зробити такі висновки.

1. Уміст гумусу у верхніх горизонтах досліджуваних чорноземів змінюється від середнього (степова цілини) до високого (байраки).

2. Гумусовий горизонт на всіх пробних площах потужний, профільний розподіл гумусу поступово спадний.

3. Ступінь гуміфікації органічних речовин змінюється від високого і дуже високого (чорноземи лісові північного варіанта байраків і чорноземи звичайні степової цілини) до середнього (чорноземи лісові південного варіанта байраків).

4. Тип гумусу переходить від гуматного (степова цілина, байрак Капітанівський) до фульватно-гуматного (байрак Військовий).

5. Уміст негідролізованого залишку чорноземів на 3 пробних площах низький і середній.

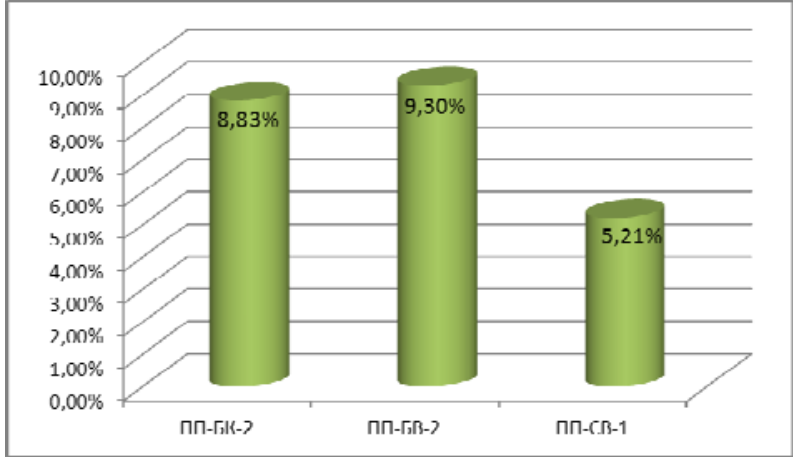

Рис. 1. Загальний уміст гумусу в горизонті $\mathrm{H}_{1} 0-10$ см досліджуваних чорноземів лісових та звичайних

6. Під впливом лісової рослинності в байраках гумусовий стан лісових чорноземів покращується, а саме загальний уміст та запаси гумусу в 20-сантиметровому шарі змінюються від середніх до високих, а тип гумусу - від гуматного до фульватно-гуматного.

7. Наші дані підтвердили положення професорів О. Л. Бельгарда та А. П. Травлєєва, що ліси в степовій зоні, на відміну від лісової зони, позитивно впливають на властивості грунту, зокрема на їх гумусовий стан.

8. Отримані дані можуть бути використані в лісовому господарстві при збереженні, відновленні природних та створенні штучних лісів в умовах степу.

\section{References}

Belgard, A. L. (1950). Lesnaya rastitelnost yugo-vostoka USSR [Forest vegetation of the southeast of the Ukrainian SSR]. Kiev (in Russian). 
Belgard, A. L. (1971). Stepnoe lesovedenie [Steppe forestry]. Forestry industry, Moscow (in Russian).

Belova, N. A., Travleyev, A. P. (1999). Estestvennye lesa i stepnye pochvy (ecologiia, mikromorfologiia, genesis) [Forest and steppe soils (ecology, micromorphology, genesis)]. Dnipropetrovsk (in Russian).

Grishina, L. A., Orlov, D. S. (1978). Sistema pokazateley gumusnogo sostoyaniya pochv [The system of indicators of the humus state of soils]. Problems of soil science. Nauka. Moscow (in Russian).

Dubina, A. A. (1972). K voprosu o formirovanii lesnoy podstilki v yestestvennykh lesakh Dnepropetrovskoy oblasti [To the question of the formation of forest litter in natural forests of the Dnepropetrovsk region]. Questions of steppe forestry, 2, 103107 (in Russian).

Nikiforov, V. V. (2008). Ekoset srednego pridneprovya - garant ekologicheskoy bezopasnosti $\mathrm{v}$ regione [Ecosystem of the middle Dnieper region - the guarantor of environmental safety in the region]. Environmental safety, 16-21 (in Russian).

Zonn, S. V. (1964). Pochva kak komponent lesnogo biogeotsenoza [Soil as a component of forest biogeocenosis]. Basics of forest biogeocenology Nauka. Moscow, 327-457 (in Russian).

Orlov, D. S., Grishina, L. A. (1981). Praktikum po khimii gumusa [Workshop on the chemistry of humus]. Moscow, 116-118 (in Russian).

Sukachov, V. N. (1964). Osnovnyye ponyatiya lesnoy biogeotsenologii [Basic concepts of forest biogeocenology]. Fundamentals of forest biogeocenology, 5-46. Nauka. Moscow (in Russian).

Travleyev, A. P. (1977). Kharakteristika pochv lesnykh kul'turbiogeotsenozov nastoyashchikh stepey USSR [Characteristics of soils of forest cultures of biogeocenoses of the real steppes of the Ukrainian SSR]. Questions of steppe forestry and nature protection, DGU, 7-21 (in Russian). 